\title{
HOUAISS.... PINHEIRO. GALINDO: AND WHAT THE FUTURE HOLDS FOR ULYSSES TRANSLATIONS IN BRAZIL
}

\author{
Caetano W. Galindo ${ }^{1^{*}}$ \\ Vitor Alevato do Amaral ${ }^{1 * *}$ \\ ${ }^{1}$ Universidade Federal Fluminense, Niterói, Rio de Janeiro, Brasil
}

\begin{abstract}
This article $^{1}$ aims to analyze the history behind the three Brazilian translations of James Joyce's Ulysses, trying to consider how each translation helped to set up the conditions for the production of another, and may even define the need for this future retranslation, which by its turn will react to that first work, filling a cultural blank space previously created only by the existence and the specific characteristics of the work that came before. In this way, we attempt to provide some clarification for the apparent abundance of Portuguese language translations of Joyce's seminal novel.
\end{abstract}

Keywords: James Joyce; Retranslation; Translation History.

\footnotetext{
"Professor at UFPR since 1998, where he teaches the history of the Portuguese language, as well as translation studies. He has a master's degree from the same university and a PhD from Universidade de São Paulo. He has translated almost 50 books, among them James Joyce's Dubliners, A Portrait of the Artist as a Young Man and Ulysses. Since 2014 he has been a fellow of CNPq, the Brazilian Council for Scientific Research. His e-mail address is: cwgalindo@gmail.com. ORCID: 0000-0002-0437-1664.

** Teaches English Language Literatures at the Department of Modern Foreign Languages of the Fluminense Federal University (UFF) in Niterói, Rio de Janeiro. His main areas of research are Joycean Studies and Literary Translation, with focus on the retranslations of James Joyce's works. He is also a researcher affiliated with the Research Group on Translation and Adaptation Studies (ESTTRADA / UFRJ), the William Butler Yeats Chair of Irish Studies (USP), and the Translation and Creation Study group (UFF). He is a member of the executive board of the Brazilian Association for Irish Studies (ABEI) and has created, with Dirce Waltrick do Amarante (UFSC), the research group Joyce Studies in Brazil (2018). His e-mail is vitoramaral@id.uff.br. ORCID: 00000001-7838-5965.
} 


\section{Introduction}

During an interview concerning the publication of the latest Brazilian translation of James Joyce's short stories, Dubliners (1914), the journalist took the opportunity to ask Caetano Galindo, himself also the translator of Ulysses (1922), why was it that the Portuguese language already had five translations of Joyce's novel. She certainly had reasons to be perplexed by this information - even though she did not mention anything about Galindo's translation of Dubliners being the eighth in Portuguese. Considering, for example, that up to today the French and the German languages have had the publication of only two translations each in the lapse of seventy-five (1929 and 2004) and forty-eight (1927 and 1975) years respectively, the question of why the Portuguese language has had five ones - all published within forty-eight years $(1966,1989,2005,2012,2013)$ - really should give us food for thought. ${ }^{2}$

The first thing we have to make clear is that there aren't indeed five different translations of Ulysses available to any given reader of Portuguese, since two of them have been published in Portugal (1989 and 2013) and three in Brazil (1966, 2005 and 2012). We, as Brazilians, do not consider ourselves to be apt readers, let alone apt evaluators of Portuguese literary translations. One cannot dream of comparing the gap faced by Portuguese speakers of the two sides of the Atlantic with the one faced by American and British English speakers. We do speak what must be considered one and the same language, in Brazil and in Portugal. Nevertheless, our ratios of intercomprehension fluctuate wildly, and are absolutely asymmetrical. For numerous phonetic and historic reasons, the Portuguese tend to be much more conversant in the Brazilian variety of the language. Brazilian music, television and even cinema have had a deep penetration in Portugal and, with them, the "brasileiro" phonetics, morphology and syntax have become second nature to many Portuguese people, whereas the contrary is definitely not true. Even the circulation of people between the two nations has changed since the second half of the twentieth century, and now tens of thousands of Brazilians make "our" variety of the language easily heard and understood in Lisbon, for instance.

But even though this coexistence may help bridge that linguistic gap, it is something especially strong in the pop domain and the linguistic varieties present in its media. The moment one starts to dig deeper, and to get away from the urban centers, the recent slang and the "received" television pronunciation, things begin to go awry. And obviously this deeper digging is something inescapable in the translation of such a profound and profoundly encyclopaedic work as Ulysses. Thence the fact that any competent translation of Ulysses in Brazil and in Portugal $^{3}$ must have been based on a process of internal research and employment of varieties that will perforce incapacitate the reader who comes from the other side of the Atlantic. These translations have to be site specific, so to speak.

That said, we can now adjust the triggering question: why are there three translations of Ulysses in Brazil if, we must add, the quantity of translations does not make the book necessarily easier to read? Why would a country that still 
suffers from low indicators in pretty much everything connected to literacy and literature produce three different translations of such a dense, "impenetrable", difficult book?

Translation Studies has supplied different motives that explain the phenomenon of retranslation, such as changes in the target-language and target-culture, financial opportunities for the editorial market, dissatisfaction with the existing translation(s), admiration for the existing translation(s), updates in the establishment of the source text, development of new theoretical and critical apparatuses, and the intention to offer a different reading of the source text (Gürçağlar; Monti). Undoubtedly, several among the motives in the above-mentioned list must have concurred to the writing and publication of the second and third translations of Ulysses in Brazil. It would be naïve to think that there was one single reason working alone. But because of the complexity of the Brazilian Ulysses case, we believe it requires a fresh insight, which we intend to give in this article.

For if we look at the three translations, we can still try to understand the process as something more internally consistent, and more dependent on the characteristics and the contexts in which each one of those works was created: something more akin to a ripple effect, where the first translation defines the need for the second (and even some of its characteristics), and where both of them, together, define the space to be occupied by the third project. (As a matter of fact, even the two Portuguese translations may be read as "responses" to challenges set by the Brazilian versions, and to their mere existence. But to be true to our confessed and unavoidable limitations as readers of the translations written in Portugal, we shall henceforth restrain ourselves to the already complicated Brazilian situation.)

\section{Ulysses in Brazil: a patchy story}

Before we discuss some aspects of the Brazilian translations of Ulysses, it is perhaps relevant to offer a few notes about the reception of James Joyce's works in Brazil. One could perhaps think that some immediate resonance of the publication of Ulysses in 1922 should have been felt in Brazil, since it was also the year of the Semana de Arte Moderna (Modern Art Week), the seminal event that defined literary modernism in Brazil. But the fact is that the high priests of our modern movement gave scant attention to Joyce, with the remarkable exception of the writer and intellectual Mário de Andrade. In June 1924, in a hardly ever mentioned article in Joyce Studies in Brazil, "Da fadiga intellectual. (Anotações sobre a poesia moderna)" (On Intellectual Fatigue. (Notes on modern poetry)), Andrade defines Ulysses as "one of the most curious books of modern English literature" and quotes, in English, a few lines (1l. 17-30 in the Gabler edition) from "Lotus Eaters" (114, our trans.).

Joyce's initial repercussion in Brazil is also due to two figures slightly separated from the modern movement, first of all because they were operating from outside São Paulo, where the "Semana" took place. The first of those two men was Sergio 
Buarque de Holanda, a historian from Rio de Janeiro, who in 1924 announced that he would publish an essay about Joyce (Mutran 428), but was beaten to it by Gilberto Freyre, a sociologist from Recife, in north-eastern Brazil, who in the same year published the newspaper article "James Joyce: o criador de um ritmo novo para o romance" (James Joyce: the creator of a new rhythm for the novel). In the next decade or so those two men were to become giants of the interpretation of our past and culture; but in that moment, and to our needs here, they remained peripheral, both geographically and in virtue of their career choices, that placed them outside the literary world.

And as that first essay about the novel came from the North-East, the first translation of an excerpt of Ulysses was to appear in the South, in Curitiba. It was there that, in 1946, in a magazine titled Joaquim, created by the young writer Dalton Trevisan, the twelfth section of "The Wandering Rocks" (11. 718-798 in the Gabler edition) was published. This translation was not signed, and for decades everyone aware of it surmised it was made by Trevisan himself. He is a known recluse and has never commented publicly on the matter. Nevertheless, we have recently obtained confirmation from himself that the translator was indeed Erasmo Pilotto, an important educator (again an "outsider") and the second mastermind behind the magazine.

There seems to have been an interest in translating Ulysses in Portugal already in the end of the 1930s. There's a handwritten letter of 1938 to Joyce by a certain A. Salema, mentioning his never realised project of publishing a serial translation in Portugal (Casado 89). But the fact remains that, although $A$ Portrait of the Artist as a Young Man (1916) had been published as "early" as 1945 in a Brazilian translation by the novelist José Geraldo Vieira, in 1964, when publisher Ênio da Silveira wrote his very proud text to the flap of the first Brazilian translation of Dubliners, made by Hamilton Trevisan (no relation to Dalton), there was still no complete translation of Ulysses in the Portuguese language.

Finally, in 1964, Silveira presented the project of translating Ulysses to Antônio Houaiss, who would become the first translator of the novel to Portuguese and, definitely, the stone throw that created all the ripples that came afterward. "Houaiss lost everything and had nothing to do", wrote Silveira, "so I commissioned him to translate Ulysses; only a man with his creativity and lexical richness could accept such challenge" (Ferreira 91; our trans.).

Before we take a look at what this translation meant, and at what it did, though, there is some more contextualization required. First of all, there's the fact that the translator was, in a certain sense, no translator at all. Houaiss was an immensely cultured man, a diplomat and a philologist who would become the editor of an encyclopaedia and the author of the best dictionary the language has ever known. He was elected member of the Brazilian Academy of Letters in 1971 and was even responsible for the language revision of the the Brazilian Constitution of 1988. But in 1965, soon after the military coup of 1964, his career in the Ministry of Foreign Affairs was interrupted after he was considered potentially subversive. Then, being contacted by the publisher with such a kamikaze proposition (translating Ulysses 
in one year), we may say he was "pushed" by history. But his courage to accept the challenge must not be diminished by his difficult circumstances. And he delivered the translation in due time. His 1966 Ulisses was the literary event of the year.

The second note one has to make in order to understand the position from which Houaiss translated the book, and the literary context to which he responded, has to do with one of the first persons to react to his translation: Augusto de Campos. ${ }^{4}$ Augusto (who was born in 1931 and made his debut as a poet in 1951) already was, and still is, a major player in Brazilian letters. Together with his elder brother Haroldo (1929-2003) they created a literary movement called concretismo, tried to redefine all ideas about poetry and, meanwhile, translated and presented to Brazilian readers a whole slew of revolutionary writers, from the middle ages to high Modernism, building what they called a paideuma (related to paedeutics), a somewhat personal canon of literary invention they employed to legitimize their own revolution-in-the-making.

In 1962 the two brothers had published Panaroma do Finnegans Wake, a selection of translated excerpts from Joyce's final work, accompanied by their original essays about the book. In a cultural scenery that by then had not even been exposed to Dubliners, they were certainly thinking ahead. As always.

Nevertheless, this also created a certain bias. After that peripheral Joyce of the 1920s, 30s and 40s, what we had now was a different image associated to his name: an image of canonization, avant-gardism, and, above all, of formal revolution. Of course, those are categories easily associated with Ulysses, and correctly so. But the fact remains that Joyce the comic writer, Joyce the democratic, Joyce the dirty and down-to-earth novelist was not much in evidence in Brazil when the king of high-brow philology accepted to give us our first Ulisses.

\section{The first translation (1966)}

Houaiss's Ulisses translates Joyce's opening words "Stately, plump, Buck Mulligan ..." (3) as "Sobranceiro e fornido, Buck Mulligan ..." (3). First of all, there is much to be discussed in his choice of reading Joyce's "stately" as an adjective, creating a syntagm of the kind "[Adj + Adj] + Noun", instead of treating it as an adverb and parsing it as "Adv + [Adj + Noun]". But the real point to be discussed is the choice of the lexicon. Though "stately" may not be one of the most common words in English, "plump" is a very homely term. The same cannot be said about the Portuguese words chosen for the opening. "Sobranceiro" is a word more associated with nineteenth century poetry, and "fornido" sounds a little twee: something we would prefer to employ between inverted commas.

Of course, there is the linguistic change factor. Houaiss's translation is half a century old now. But the fact remains that the book opens with a clear overstatement of its quaintness, and with a clear dislocation of its tone toward the archaic and the elevated. The same Augusto de Campos called attention to Houaiss's "arcadic taste", underlining that some of the solutions in his translation tended to "inflate" the text with a sort of "erudition which does not correspond to the original" (179). On the 
whole, we find a general tendency of Houaiss to raise the bar and give the reader a much denser and much more erudite version of Joyce's text.

What is ironic in a sideways way is that, seen from today, this tendency to "elevate" Joyce's register and prose can be considered as much a fruit of its translator's background and personal style (as it always shall be) as a fruit of that position in which Joyce was being placed in the Brazilian cultural system of those years, a movement curiously spearheaded by the Campos brothers themselves. Joyce, then, was an author "for the few" (and should remain that way), a prose writer read and defended not only by Brazilian poets, but by a new generation of iconoclastic poets who, by association (and not necessarily by any conscious and active posture to that end), would, probably unintentionally, brand him as an "elite" writer (and even "elitist").

Let's remember this was happening as a sort of "side effect" of the extremely important, valid and relevant efforts of the Campos brothers to try and put Brazil up to speed in terms of literary creation. Let's also remember that all of this was happening before the full impact of the tidal changes that happened in the reception of Joyce (and particularly Ulysses) during the 60s and the 1970s, helping to reposition his work in the tradition of the novel, as a universal "classic".

Of course such a cursory "analysis" of a huge effort of translation does not justify a thorough critique. And it is obvious also that we must factor the situation, the critical context in which Antônio Houaiss produced his veritable monument. We have the utmost respect for the results he managed to obtain in his working conditions here in Brazil, in the mid 1960s, with a mere fraction of the apparatus we can access today (think of the pre-Internet world), rushed by a one-year schedule, with no previous background in literary translation. Nevertheless, this reading, anchored in that first exemplification, can indeed show the bias created for the translation even before he put proverbial pen to paper.

It was the first full translation of Ulysses in Portuguese, and as such it opened the whole series of responses and reactions that came to categorize the history of Ulysses in Portuguese. But even as the "first", his work was not produced in a vacuum, undetermined by a previous tradition and by the specificities of the cultural milieu that enabled even the initiative to translate that book in this country in that moment.

This first "move" in our game was to determine much of the reception (in how it happened and, perhaps more importantly, in how it did not happen during the following decades) of Ulysses in Brazil and in the Portuguese speaking community as a whole. There was even (which is very far from being the rule) a printing of Houaiss's translation in Portugal, with minimal orthographic alterations, in 1983 (Figueiredo).

\section{The second translation (2005)}

The second translation made in Brazil, on the other hand, did not have an alternative. It had to be read, and even written, as a "reaction" to the first one. 
Houaiss's translation, after all, was the only version of Ulysses in Brazil for almost forty years. One, maybe two generations were literarily "raised" on such a diet. That first Ulisses could not be ignored. And it wasn't.

But, first of all, the profile of the second translator could hardly be more different. The only big thing Bernardina da Silveira Pinheiro had in common with her predecessor is the fact that she was, and remains, someone with little involvement with literary translation as a regular activity. As a matter of fact, when she translated A Portrait in 1992 (in what was also a "second" translation after almost fifty years...) she had her first contact with the activity; and in the interval that separated that work from her Ulisses, she translated only one other novel: Laurence Sterne's Sentimental Journey.

Only seven years younger than Houaiss (who, being born in 1915, published his translation when he was forty-one), Pinheiro was already a qualified Joycean, studied with Richard Ellmann, and published widely on Joyce and psychoanalysis. Even more important, she was to publish her translation, elaborated during a more dilated period of time (seven years), exactly thirty-nine years after his, being able to count on a whole broader selection of critical texts, books and even online sources. She also worked from a different text, after her publishers bought the rights to use the Gabler edition, and she even provided a "translator's introduction" and hundreds of notes which would become the first big contribution in the process of giving the Brazilian readership a deeper critical access to the meanders of Joyce's great novel.

All those divergences helped, of course, to generate a very new version of Ulysses. But the sheer "belatedness" of her position may never be underestimated. As an editorial policy as well as an artistic declaration, she had to establish herself, if not necessarily as an "anti"-Houaiss, at least as a valid alternative to his work.

The fact that she provided an introduction to her translation allows us to try to understand her criteria from her own words. One thing she underscores constantly is her interest in the musicality of Joyce's prose, which can indeed be considered one of the losses derived from the erudite take detectable in Houaiss's work. But the one example she examines in the introduction, pointing to such a musical solution, may also illuminate a set of decisions that, although confirming her democratic attitude, her repositioning of Ulysses as a more legitimate representative of the tradition of the popular comic novel, can also be read differently, highlighting a sort of concern with the immediate access of the reader to the text (diametrically opposed to Houaiss's attitude, therefore) that can sometimes come out as "simplification".

She chose to comment the phrase "If others had her Will, Ann hath a way", a true nightmare for any translator, of course, since we do have a pun, and, more than that, a pun anchored in names that not only have no meaning in Portuguese but are sometimes unpronounceable by speakers of Portuguese. She is unquestionably right to pinpoint such an example as a crucial difficulty. But her solution is also (as all solutions will of course be) questionable. She writes "Se as outras têm sua vontade, Ann tem sua veneta", something like "If others have 
their will, Ann has her whim", with an alliteration not unlike the one accidentally generated in English by this impromptu translation (Pinheiro xv-xvi).

So, she traded a pun for sound play. But if a pun has a "meaning", when it appears in the speech of a given character (Stephen, in this instance, and a drunken Stephen at that) it also has an effect: it "means" something about that person, the image they want to project etc. And there is no such effect if the translation doesn't try to render the wordplay. In doing so, she has somehow lost sight of both the locutionary and the illocutionary acts.

The next isolated example Pinheiro analyses is the famous "slip" in which the woman who signs herself as Martha Clifford changes what should have been a "word" to a "world". And what she says there is baffling, for she declares her choice to translate "world" as planeta [planet], a word that does not hint at any possible slip (Pinheiro xvi). The reader of the original can understand that Martha made a mistake and can then try to interpret her Freudian motives. The Brazilian reader, exposed only to Pinheiro's Ulisses, can only think Martha was actively trying to say something very different. And what could that even be?

By choosing only the bits she herself separated for analysis, we can hope to avoid our own biases. And, of course, it's not such a stretch to imagine she herself considers those examples to be effectively representative of her translating "poetics". They do point to an ideal of "comprehensibility" and to an effort to grant access to the text, an effort to be "colloquial" when Joyce also was (her words in the Introduction), but also to a strategy that ends up skipping over some wordplay in order to generate a more transparent, and perhaps more "musical" text.

The opening words, for instance, instead of pertaining to an older and more elevated language register, in Pinheiro became "Majestoso, o gorducho Buck Mulligan [...]" (4), parsing the phrase with an adjective which modifies the whole syntagm (operating therefore somewhat as an adverb) and employing common and even "popular" words (gorducho would be something like "chubby"). She leaves out the concern with an initial "S", of course, and she also chooses to go for a much more defined translation of "plump" (a "polemical" adjective, definitely colored by Stephen's opinions and ill-will concerning Mulligan). But, above all, she signals from word one her position and her attitude, antipodal to that of Houaiss.

\section{The third translation (2012)}

Having started working on his translation in 2002, Caetano Galindo was already dealing with it in 2005, when Pinheiro's translation appeared. And that made a difference. Even before he finished his first "final" version (which would happen only in 2006), his placement in the system was radically and definitely altered. Now he was the third person.

Galindo (1973 -) also comes from a different background. He was born more than fifty years later than Pinheiro, and seven years after the publication of the first Brazilian Ulisses. When he began working on the translation, he also had 
published no other literary translations. But in 2012, when his Ulysses (with a "y") was finally published, it was his 25th translated book. The translation was initially part of a doctoral thesis that was delivered in 2006, and from then on he has translated Finn's Hotel (2014), A Portrait (2016) and Dubliners (2018). More than that, if Houaiss was already a giant in his field, and if Pinheiro was the consummate Joycean, Galindo came unquestionably out of left field; after all he was a fairly young university teacher still on the way to establish himself in the Brazilian literary scene, and coming out of the central axis of Brazilian culture, represented by Rio de Janeiro and São Paulo.

In 2012, Brazil was already a different environment. Augusto de Campos is, of course, alive and quite literally kicking, as a very active voice in the poetic debates of this early twenty-first Century, but the cultural scenery, it goes without saying, is not what it was in the mid 1960s. Joyce has been translated and retranslated. Today we have five full versions of Dubliners and A Portrait, three of Ulysses and countless other translations of his poetry, essays, letters, drama and fiction. The literary system and its notions of "centrality" had also changed by the beginnings of the 2010s. And all that would of course generate quite a different Ulysses when Galindo's turn came to make his work public.

A different editorial market, also, has allowed his translation to be released with a lengthy foreword by an influential Joyce Scholar (Declan Kiberd). And if the book did not have any notes, it was followed (2016), by the first Companion to be published in Portuguese, going one step further in the process of democratization initiated by Pinheiro. We are not in a comfortable position to analyze this translation's eventual hits and certain misses (all too obvious to at least one of us). More important than any (im)possible comparison of results, though, is the relative "position" occupied by this translator and his predecessors in the work on Ulysses in Brazil.

If in the beginning the third translator produced a full version of each episode, revised it, and then went on to read it side by side not only with Houaiss's work, but also with the French (1929), the Italian (1960) and the Spanish (1945) translations... sentence by sentence, it took him only a couple of tries to realize this would cripple him. The translator of a work of such complexity is faced with so many choices, and so many choices of choices that although a working knowledge of the results of as many of the previous translations they can read is of course relevant and beneficial, a state of total confrontation, in which they try to conceive of all their paths as an active response to those predecessors, might lead to full stasis... to interruption.

If one is working as the second in a given context, he or she can have this role imposed upon him or herself. For the translation will be read as a reaction, it will be read comparatively. But when the work is to be the third rendition of the novel in a given country, it can be simultaneously more and less subject to that "comparison". For one, the readers do have two other points of reference before they get to the third translation. On the other hand (and that was pretty much the situation in Brazil) when the second translator has performed her task so 
completely, creating the obverse of the inaugural work, the space left is the fertile middle ground, the continuous cline between both poles, that reacts to each one of them, avoiding at the same time the need to be read as an active response to any one of them in particular.

After translating maybe four episodes, he stopped comparing his translation to that of Houaiss. And to any other. And although Pinheiro's work has served him well while teaching whole courses about the novel, it was not read while he worked on his translation. Nevertheless, the mere existence of such well-defined "extremes" has created a situation in which any translator couldn't help but be influenced by the experience of the predecessors and, of course, of decades of reading of one and then the other version of the novel.

In trying to avoid the Scylla and Charybdis of (perhaps) ungranted "erudition" and "simplification", the translator must have made his own mistakes. But they are only his own because they had been preempted (and maybe also prompted) by those two first works.

Looking again at the aforementioned opening of Ulysses, we notice for instance that Galindo's rendition of the adjectives "stately, plump" contrasts blatantly with Houaiss's lofty "sobranceiro, fornido", and gets closer to Pinheiro's "majestoso, o gorducho", both in trying to avoid the rare and perhaps quizzical word choices of the first translation and in looking for a reading in which the second adjective creates a noun phrase with the name Buck Mulligan: "Solene, o roliço Buck Mulligan". At the same time, he aligns himself with Houaiss in trying to keep the initial "S".

So, even in such a small example, we can find the marks of a work that knows itself to be "belated", to be the third person. This new translation may have its advantages (maybe "solene" retains a bit of the adverbial reading of "stately"), and may also have its problems ("cíngulo" is a very rare word, used only in the church, and maybe the use of "ungirdled" in the original did not call for such a direct response). Whatever the readers' judgements, it is never going to be fully independent of the parameters set by its predecessors.

\section{Conclusion}

The examples we singled out from the three Brazilian translations do not stand for the translator's failures, but for their attitudes towards Joyce's text while dealing with very complex translation cases. With them, we have tried to demonstrate that Houaiss, Pinheiro, and Galindo approached the text of Ulysses each in a personal and original way, rendering solid and organic translations, but from which controversy is not absent.

It is still not clear why Brazil came to be a hotspot for translations of Ulysses. But after this essay, we can see some general trends connected to the process of reading and writing Joyce's novel in Brazil. For one thing, peripheral Brazil seems to have had a huge role in the entire process and, in recent times, southern Brazil has again occupied quite a "central" position in Joycean studies. The 
first Brazilian translation of Finnegans Wake, by Donaldo Schüler, and most of the research and publications about Joyce's final work by Galindo (2016), and specially Dirce Waltrick do Amarante have come from the three southernmost states: Rio Grande do Sul, Paraná and Santa Catarina respectively.

There is also a slow change of the guard happening. Schüler (born in 1932) may serve as point of contact. But much of the recent production inside and outside of academia comes from persons born after 1960. A whole new generation which has also come to grips with a new relation between universities and the publishing market, and with the rise of a new sort of literature in Brazil, for the first time in decades exposed to the wonders and the dramas of the middle-brow novel. This has given us a new Joyce, too. A writer with a closer connection to the tradition in which most novelists operate in Brazil and, curiously, also a writer whose reception is more rooted in academia.

We suspect that the total number of Portuguese language translations is somewhat influenced by the curious situation of sameness/difference that obtains between the two countries speaking the language, a situation which tends to generate mirror reactions and supplementary works. And the clear tendency observed, even in the chronology of the translations, in which Portugal "responds" to the Brazilian works, even though leaving something to be explained (why Brazil first? What's in our "spirit" that makes us interested in such a book? Is everything to be explained by that "second" modernist wave and its huge impact in our literary culture?), leads to an unimpeachable demonstration: everything has begun with that one-year effort by a non-translator, working in almost heroic conditions and producing a work that, determined as it may have been (and as it surely was, in our reading) by a general trend in our "avant-garde" of those days, opted for an attitude, for a way of dealing with Joyce's inventions that not only set the ball in motion but, extreme as it was, ended up creating a very wide space for reaction.

In the response-and-mirror movement that characterizes the context of the Ulysses translations in the Portuguese language, the real question seems to be why it took so long for Ulysses to be translated for a second time in Brazil. In other words, why no one had that kind of bravery to face the double challenge of translating Ulysses and facing Houaiss's legacy for almost forty years. We have much to thank Pinheiro for daring to do it and for doing it in such a responsible and conscious way. But the gap remains to be explained. And it is unfortunately to be partially explained by the size of the publishing market and by its semipermanent state of crisis.

Nevertheless, there is a second possible explanation. By going wide in one direction, and by choosing what could have been seen as the direction of elitism, the first Brazilian translation may have defined on the one hand the automatic need for a second translation (something that can be said of pretty much all first translations). But, on the other hand, it may have consigned the novel to a more restricted "pocket", keeping it somewhat distant from the interests of mainstream prose writers and readers, and helping (inadvertently) to postpone that second translation whose need was at same time obviated by its existence. 
It's a fool's game, trying to analyze counterfactuals in history. But it's not such a wild guess to suppose that the "reaction" (taking the form of a new translation) could have been much faster had the first one chosen the "democratic" "pole", that is, the opposite extreme. Houaiss's work, on the contrary, isolated the novel among the "knowledgeable" readers, and kept it from the hands of perhaps a full generation of possible translators. And when the response came, after so many years, it had to be as extreme an opposition as it was.

To conclude, there is no three-Ulysses problem in Brazilian literature. There is the constant struggle of the culture to deal with Joyce's novel in a permanent, critical and active dialogue of readings and translations. There are three different translations because there were three different translators, working in three different contexts. But, since they were always reacting to one or more previous translations in the same language (Palma-Ferreira, Pinheiro, Galindo, and Carvalho) or creating the conditions that determined the future work to be done (Houaiss), the future certainly holds more to come, and the problem of the Ulysses translations, either in Brazil or in the Portuguese language in general, cannot be informed by numbers (three or five). There is only continuous translation.

Notes

1. This essay is the expansion of some preliminary remarks afterwards removed from a chapter one of us wrote for a forthcoming book organized by Jolanta Wawryzcka and Erika Mihalycka.

2. Something similar happens in Spanish, which also has five translations of Joyce's novel $(1945,1976,1999,2015,2017)$. Like the situation in the Portuguese language, the first translation of Ulysses into Spanish was published in Latin America (Argentina), not in Europe.

3. Up to this moment, there is no translation of Ulysses from one of the lusophone African countries.

4. We refer to a series of five articles (June-July 1966) in the newspaper O Estado de São Paulo, later published together as "De Ulysses a Ulisses" (Campos, Augusto 171).

\section{References}

Andrade, Mário de. "Da fadiga intelectual (anotações sobre a poesia moderna)". Revista do Brasil, vol. XXVI, no. 102, June 1924, pp. 113-121.

Campos, Augusto de, and Campos, Haroldo de, editors and translators. Panaroma do "Finnegans Wake". 1962. $4^{\text {th }}$ ed. Perspectiva, 2001.

Campos, Augusto de. "De Ulysses a Ulisses". Panaroma do Finnegans Wake, $4^{\text {th }}$ ed., edited and translated by Augusto de Campos, and Haroldo de Campos, Perspectiva, 2001, pp. 171-193.

Casado, Carmelo Medina. "The Earliest Translations of Joyce's Ulysses". Papers on Joyce, no. 16, 2010, pp. 81-91.

Ferreira, Jerusa Pires, editor. Ênio Silveira. In the series "Editando o editor" [editing the publisher], vol. 3, Edusp, 2003.

Figueiredo, Vivina Almeida Carreira de Campos. "Joyce em português europeu". $O$ Lingua, no.6, April 2005. cvc.instituto-camoes.pt/olingua/06/lingua02.html 
Freyre, Gilberto. "James Joyce: o criador de um ritmo novo para o romance". Diário de Pernambuco, 11 December 1924, p. 1. memoria.bn.br/DocReader/docreader. aspx?bib=029033_10\&pasta $=$ ano\%20192\&pesq=James\%20Joyce

Galindo, Caetano Waldrigues. Sim Eu Digo Sim: uma visita guiada ao "Ulysses" de James Joyce. Companhia das Letras, 2016.

Gürçağlar, Şehnaz Tahir. "Retranslation". Routledge Encyclopedia of Translation Studies, $2^{\text {nd }}$ ed., edited by Mona Baker, and Gabriela Saldanha, Routledge, 2011, pp. 233-236.

Joyce, James. Dublinenses. Translated by Hamilton Trevisan, Civilização Brasileira, 1964. 2012.

Dublinenses. Translated by José Roberto O’Shea, Siciliano, 1993, Hedra, Dublinenses. Translated by Guilherme da Silva Braga, L\&PM, 2012.

. Dublinenses. Translated by José Roberto O'Shea, Hedra, 2012.

. Dublinenses. Translated by Margarida Periquito, Relógio D’Água, 2012. 2018.

Dublinenses. Translated by Caetano W. Galindo, Companhia das Letras,

. Gente de Dublim. Translated by Virgínia Motta, Livros do Brasil, 1963.

. Gente de Dublin. Translated by Isabel Veríssimo, Publicações EuropaAmérica, 1994.

. Finn's Hotel. Translated by Caetano W. Galindo, Companhia das Letras, 2014.

. Finnicius revém [Finnegans Wake]. Translated by Donaldo Schüler, Ateliê Editorial, 1999-2003. 5 vols.

. Retrato do artista quando jovem. Translated by José Geraldo Vieira, Livraria do Globo, 1945.

Um retrato do artista quando jovem. Translated by Bernardina da Silva Pinheiro, Siciliano, 1992.

. Ulysses. 1922. Edited by Hans Walter Gabler, Vintage, 1986.

. Ulises. Translated by José Salas Subirat, Santiago Rueda, 1945.

. Ulises. 1976. Translated by José María Valverde. Lumen, 2014.

. Ulises. 1999. $7^{\text {th }}$ ed. Translated by Francisco García Tortosa, and María Luisa Venegas Lagüéns, Cátedra, 2009.

. Ulises. Translated by Marcelo Zabaloy, El Cuenco de Plata, 2015.

. Ulises. Translated by Rolando Costa Picazo, Edhasa: 2017.

. Ulisses. Translated by Giulio de Angelis, Mondadori, 1960.

. Ulisse. Translated by Antônio Houaiss, Civilização Brasileira, 1966.

. Ulisses. Translated by João Palma-Ferreira, Livros do Brasil, 1989.

. Ulisses. Translated by Bernardina da Silveira Pinheiro, Objetiva, 2005.

. Ulisses. Translated by Caetano W. Galindo, Companhia das Letras/Penguin Books, 2012. 2014.

Ulisses. 2013. $2^{\text {nd }}$ ed. Translated by Jorge Vaz de Carvalho, Relógio D’Água,

Ulysse. 1929. Translated by Auguste Morel. James Joyce. Euvres, vol. 2, edited by Jacques Aubert, Éditions Gallimard, 1995. 2 vols. 
Ulysses. 1927. Translated by Georg Goyert, Deutscher Taschenbuch Verlag, 1966. 2 vols.

Ulysses. 1975. Translated by Hans Wollschläger. Suhrkamp, 2013.

Ulysse. 2004. Revised in 2013. Translated by Jacques Aubert, Pascal Bataillard, Michel Cusin, Sylvie Doizelet, Patrick Drevet, Stuart Gilbert, Bernard Hopffner, Valery Larbaud, Auguste Morel, Tiphaine Samoyault, and Marie-Danièle Vors, Éditions Gallimard, 2014.

Monti, Enrico, and Schneyder, Peter, editors. Autour de la retraduction. Perspectives littéraires européennes. Orizons, 2011.

Mutran, Munira. "A recepção de James Joyce no Brasil". Riverrun. Ensaios sobre James Joyce, edited by Arthur Nestrovski, Imago, 1992, pp. 427-446.

Pinheiro, Bernardina da Silveira. Introdução [introduction]. Ulisses, by James Joyce, translated by Bernardina da Silveira Pinheiro, Objetiva, 2005, pp. ix-xvi. 